Jorge Louraço Figueira

é critico de teatro do

jornal Público e dramaturgo.

\section{Jorge Louraço Figueira}

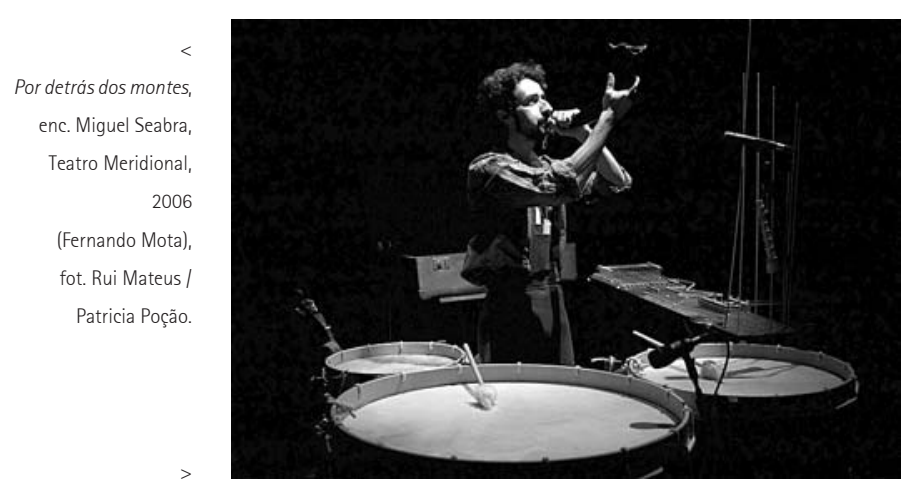

Por detrás dos montes, enc. Miguel Seabra,

Teatro Meridional,

2006 (Mónica Garnel

Pedro Martinez, Pedro Gil

Carla Maciel

e Carla Galvão),

fot. Rui Mateus

Patricia Poção.

Para mais informações

sobre a música de

Fernando Mota

aconselha-se a consulta

da sua página pessoal em

http://go.to/fernandomota

bem como o sitio do

Teatro Meridional

http://www.teatro

meridional.net
Uma das minhas recordações mais perenes é de uma viagem na Linha da Beira Baixa, devia ter oito anos, ouvindo o cavalgar da carruagem Tejo acima. Hoje, vindo do Porto, não se ouve nada, ou, o que é muito pior, ouve-se música pop de segunda categoria quando o Alfa Pendular pára em Coimbra $B$ para receber passageiros. Por isso só posso ficar muito grato a um músico que dá de beber água pura e vinho maduro, em vez de refrigerante industrial.

A menção especial a Fernando Mota, em reconhecimento pela invulgar contribuição para o panorama artístico nacional, pela música e espaço sonoro do espectáculo Por detrás dos montes, deve-se ao modo como a sua arte condensa e reconstitui as paisagens sensoriais do nordeste transmontano de forma bela e singular, e em plena cumplicidade com essa criação do Teatro Meridional.

0 intérprete e compositor surge como actor de corpo inteiro neste espectáculo em que os performerse a performance são um todo, e onde as palavras têm peso e medida semelhantes $a$, não maiores que, os outros instrumentos teatrais. Seria impossível, é claro, desligar essa performance das restantes, incluindo a encenação e a realização plástica, cujo movimento se inicia no começo de cada espectáculo tanto como os gestos dos actores (e já vão nas dezenas de representações) e do músico. Mas na verdade, Fernando Mota parece não só o músico ou o actor, mas a orquestra Fernando Mota, ou pelo menos a filarmónica, tal é a abundância e variedade de sons que coloca ao dispor dos espectadores. 0 trabalho é tão completo e perfeito que expõe os limites do discurso crítico. Se o próprio músico escreve, no programa do espectáculo, sobre o lado contemplativo da arte, levando a sua música pelos campos do indizivel, como ele diz, citando John Cage, por um lado, e a suficiente metafísica

\title{
Vista sonora para Trás-os-Montes
}

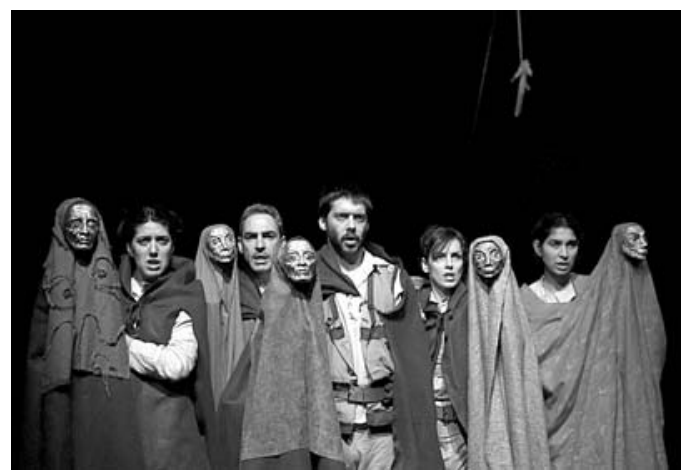

de não pensar em nada, de Alberto Caeiro, por outro - e se concretiza essa inspiração de modo tão admirável - e tudo isso editado em disco que se pode levar para casa - o que resta a um crítico senão aplaudir e recomendar a compra? Palavras para quê? É um artista português...

Por isso, nesta minha intervenção estive tentado a forçar-vos a escutar o silêncio, passado estes poucos segundos, como na célebre composição de John Cage, que dura 4'33", o que talvez fosse uma forma de premiar o trabalho do Fernando Mota, e teria a vantagem de me conduzir até ao final do meu tempo de intervenção sem necessidade de dizer mais irrelevâncias - (Pausa.) Mas isso não seria uma Menção. E, por outro lado, neste caso importam também as ideias. Articulando sons e silêncios, ditos e feitos, Por detrás dos montesé uma colagem de fragmentos teatrais que reinventa as narrativas, a propaganda e o folclore sobre aquela região, e se recria como miradouro e arena, desdobrando os pontos de vista sobre gestos e hábitos. Além disso, explora a cumplicidade com os espectadores, não deixando de os provocar e de Ihes mostrar coisas novas, ou melhor, novas maneiras de ver (e ouvir) as mesmas coisas.

Ao conceber uma obra que proporciona ao espectador a viagem pelos sons de Trás-os-montes, Fernando Mota faz com que sejamos um bocadinho menos duros de ouvido. Noutra região do globo, os Inuit têm cerca de cem palavras diferentes para designar as diversas variedades de neve, que reconhecem com a mesma facilidade que um naturalista reconhece as diversas espécies de bichos, e um músico distingue uns sons dos outros. Seria uma pena que houvesse apenas um tipo de neve, um tipo de insectos, e o mesmo tipo de música pop de segunda, sempre os mesmos sons, de Norte a Sul, no lugar de aboios, que (sei agora) são metade voz, metade chocalhos. 